\title{
Surfaces
}

\section{Introduction, Feminism Beside Itself Again}

\section{Diane Elam}

Volume 7, 1997

LE FÉMINISME HORS DE LUI-MÊME

FEMINISM BESIDE ITSELF

URI : https://id.erudit.org/iderudit/1064800ar

DOI : https://doi.org/10.7202/1064800ar

Aller au sommaire du numéro

Éditeur(s)

Les Presses de l’Université de Montréal

ISSN

1188-2492 (imprimé)

1200-5320 (numérique)

Découvrir la revue

Citer ce document

Elam, D. (1997). Introduction, Feminism Beside Itself Again. Surfaces, 7.

https://doi.org/10.7202/1064800ar d'utilisation que vous pouvez consulter en ligne. 


\section{Introduction Feminism Beside Itself Again}

Diane Elam

University of Wales

Cardiff

Surfaces Vol. VII.101 (v.1.0A - 22/06/1997) - ISSN: 1188-2492

Copyright for texts published in Surfaces remains the property of authors. However, any further publication should be accompanied by an acknowledgement of Surfaces as the place of initial publication.

Feminism has never been one to stand by conventions. It has asked us to reflect on everything from our daily routines to our political habits and philosophical reflexes. Feminism has made us look at our lives with an attention to difference, with an eye to departing from doing things the way they have always been done. Conventions, it has shown us over the years, are all too often inflected with explicitly sexist outcomes: Who is suppose to take care of the children? Who is suppose to speak, and who is suppose to listen? Who performs what job? Who gets paid what? Who's on top?

While feminism has devoted much of its time to turning around the blatantly sexist habits of everyday life, it has also taken on the more subtle ways in which patriarchy has perpetuated itself through seemingly benign forms of representation and ways of thinking. In this regard, feminism's departure from convention has led to various forms of appropriation and experimentation: women writers taking over traditionally male literary genres like detective fiction; women making women centered pornography; feminists breaking from the usual linguistic restrictions of philosophical discourse; feminists challenging the approved and established 
subject matter of figure painting. Sarah Peretsky, Pat Califia, bell hooks, Helene Cixous, and Judy Chicago are not business as usual.

The essays that follow in this volume of Surfaces are themselves no upholders of convention and constitute a modest feminist experiment. It is by now a tried and true academic convention that one holds a conference and then develops a book or an issue of a journal out of the proceedings. And in itself this is certainly neither a bad nor necessarily an anti-feminist thing to do. It is, however, a format that tends toward endings and closure rather than encouraging ongoing conversations. The written text suggests that the issues at hand are now less open to debate, more a conclusion than a beginning. The open-endedness of the conference talk and the question session that follows is then overcome by the march toward the inevitable horizon of the definitive written text, less subject to change and revision.

These essays are not produced out of this conventional trajectory of academic debate and publishing. By disrupting the traditional sequence of events, they try to create a space for ongoing debates and conversations about and within feminism. While the essays collected here do indeed result from a conference, it was also a conference that followed rather than preceded the publication of a book. The risk, of course, was that to begin with a book was to begin with already firmly held positions, less not more open to debate. But that risk was worth taking.

In the first instance, a series of conversations led to collecting a group of essays that make up the anthology that Robyn Wiegman and I edited: Feminism Beside Itself (Routledge, 1995). In the beginning was the book, but the book was not the last word. Many of the essays in Feminism Beside Itself worried about settling into a heterodoxy that fixes itself like the ink on the page, a sentiment that seemed reflected in the problem the printer had with all the copies of the book: for several days the ink refused to dry on the covers.

In all respects, this anthology was not conceived as a finished project that set out to provide the last word on the current state of feminism. Continuing in that spirit, the conference held in the Spring of 1995 at Indiana University was designed not to complete what the anthology set out to do; it was not trying to finish unfinished business. Rather, the aim of the Indiana conference was to provided a working environment in which a number of feminists could continue some of the 
conversations from the anthology but also take up new topics that the book failed to address. The speakers were thus not only contributors to the anthology but also new voices who offered differing perspectives, different avenues for discussion.

The conference itself revolved around six roundtables: "Feminism and the Future of Women's Studies," "The Identities of Feminism," "Generational Anxieties," "Body Stuff," "Erotic Politics," and "The Futures of Feminism." Speakers presented short position papers, followed by panel discussions that then opened into audience forums. The essays that follow are adaptations of a selection of those position papers. But they should not be seen as finished pieces; they are still meant to be read in every sense of the word as working papers, as unfinished business designed to be presented in an electronic forum that encourages conversation, debate, revision. If anything, what the alignment of the conference, the book, and the Surfaces essays points to is the impossibility of a comprehensive and completely representative feminism. Feminism is itself an ongoing conversation.

It is this sense of ongoing conversation and reflection that could be said to be one of the driving forces behind a desire to look at feminism beside itself. "Feminism beside itself" names a certain anxiety within feminism, an anxiety brought on by feminism's very success and public visibility. With success also came a recognition of certain failures, worries about whether feminism's success could continue at the same pace. Conventions have been broken, routines examined to good purpose, but how much longer could, can, feminism continue its string of successes?

This is, of course, not such a bad problem to have, insofar as feminism's success is something to be celebrated rather than mourned. More precisely and more significantly the problem for feminism lies in the difficulty it seems now to be having in the wake of those successes. Feminism is, as it were, going through a sort of mid-life crisis, perhaps fighting but also succumbing to the stereotypic conventions associated with such a phase. Feminism has reached a point where it is not clear what it understands itself to be: What exactly is feminism? What are its aims? Its goals? How can and should its history be told?

Putting feminism beside itself means thinking about these questions, thinking about how feminism reflects on its own identity, its own goals, and its own history. "Being 
beside itself" is a form of self-consciousness, a selfreflection on the part of feminism that would not, however, signal that feminism would only look at itself and stop doing things. To put this another way, "feminism beside itself" is self-reflection in the face of activism.

The reflection on feminism, feminism's reflection on itself, certainly does not stop with the Feminism Beside Itself anthology, or with Feminism Beside Itself: A Conference, or with the essays that follow here. Each of these moments are both points of arrival and points of departure, directed toward the question of the future of feminism. In a sense, we already are in the future of feminism: we are living in the future that feminism has helped create. We are now living in what the future used to look like: we are living a feminism that once will have been.

To say "future" here is, however, not quite right. The future is better thought in the plural, for to speak of "futures" holds open the possibility of many different futures. And if we are to think in terms of futures, we should also think in terms of feminisms. Feminism is, in a sense, already divided from itself, beside itself, and marked as plural. The issue is not so much the future of feminism as it is the futures of feminisms. Today it is not easy to see a common front in or for feminism, and how to negotiate these differences may itself be one of the futures of feminisms. The futures of feminisms that will have been.

Accueil Surfaces | Table des matières | Recherche Surfaces Home Page | Table of Contents | Search

PUM | Livres | Revues | Publications électroniques | Vente et distribution 